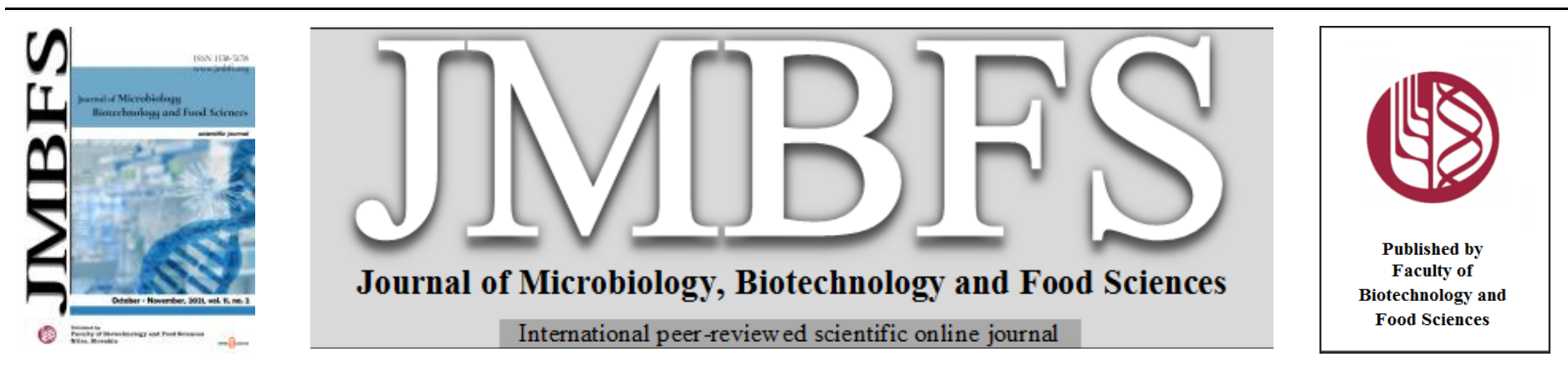

\title{
COMPARISON OF THE COOKING CHARACTERISTICS AMONG TRUE POTATO SEED (TPS) AND SEED POTATO VARIETIES AFTER MICROWAVE HEATING
}

\author{
Tropa Taufique ${ }^{1,2}$, Tuhin Suvra Roy ${ }^{2}$, Rajesh Chakraborty ${ }^{2}$, Maruf Mostofa ${ }^{* 3}$ and Bimal Chandra Kundu ${ }^{4}$ \\ Address(es): Maruf Mostofa, \\ ${ }^{1}$ Department of Bioproduction, Faculty of Agriculture, Yamagata University, 1-23 Wakaba Machi, Tsuruoka 997-8555, Yamagata, Japan. \\ ${ }^{2}$ Department of Agronomy, Faculty of Agriculture, Sher-e-Bangla Agricultural University, Dhaka-1207, Bangladesh. \\ ${ }^{3}$ Institute of Seed Technology, Sher-e-Bangla Agricultural University, Dhaka-1207, Bangladesh, Phone number: +880-1719-207566. \\ ${ }^{4}$ Tuber Crops Research Centre, Bangladesh Agricultural Research Institute, Gazipur-1701, Bangladesh.
}

*Corresponding author: marufsau@ @otmail.com

https://doi.org/10.15414/jmbfs.1327

\section{ARTICLE INFO}

Received 25. 2. 2019

Revised 24. 3. 2021

Accepted 8. 4. 2021

Published 1. 10. 2021

Regular article

open ${ }_{\text {Aackess }}$

\begin{abstract}
The microwave heating has become widely popular in potato processing because of its high heating rate, short processing time, and for controlling undesirable changes in starch. In the experiment potato columns of TPS potato 'BARI TPS-1' and local potatoes 'Diamant', 'Tel Pakri' and 'Romana' were heated with $50 \mathrm{~mL}$ of water for 0, 20, 40, 60, 90, 120, 240, and $300 \mathrm{sec}$ by a microwave oven; and the changes in potato columns were analyzed physiologically and histologically to investigate how potato tuber and starch condition changes in local potato and TPS tubers after microwave heating. The 'BARI TPS-1' potato columns resulted comparatively higher rate of weight loss and firmness loss percentage than the other seed potato varieties, indicating that temperature rapidly increased in TPS tuber columns than that of the others. Among local varieties 'Tel Pakri' gave a relatively higher weight loss and firmness loss percentage than the others. This study also showed comparatively higher solubility percentage in 'BARI TPS-1' tuber than the other local varieties, suggesting rapid disruption of swollen starch granule and faster starch degradation in TPS than the other local potato starches. Scanning Electron Microscope (SEM) images of starch granule showed rapidly ruptured and clumped starch granules in 'BARI-TPS-1' than the others, indicating TPS starch might obtain gelatinization temperature within a shorter period of microwave heating than that of the other varieties.
\end{abstract}

Keywords: Firmness, microwave heating, potato, starch granule, TPS

\section{INTRODUCTION}

Microwave heating is recently being widely used in processing and cooking of potato (Solanum tuberosum L.) tuber products including boiled potato, salad, mashed potato, chips, french-fry, starch and alcohol due to its uniform heating and reduced cooking time (Vollmer, 2003). Microwave energy induced significant changes in physicochemical and textural properties of potato tubers, which contributed to the quality of processed potato products (Sadowska, 2005; Vadivambal and Jayas, 2008). The cooking characteristics of potato tubers are also influenced by the properties of different potato cultivars (Maragoni and Yada, 1994; Wilson, 2002).

There are several studies on how microwave treatment affects potato tuber quality. Different cooking conditions have significantly different effects on the properties of potato tubers (Yang, 2016). Weight loss and reduction of firmness in microwave-treated Russet potato tubers after treating by microwave for $0.5,1$, and 2 min at 46, 65, and $90^{\circ} \mathrm{C}$ temperature, respectively (Huang $\boldsymbol{e t}$ al., 1990). Microwave energy produced comparable softening than conventional heating upon a prolonged heating time (Collins and McCarty, 1969). It was also reported by Orsat et al. (2005).

Microwave radiation affects the physiochemical properties, structure, and behavior of potato starches (Lewandowicz et al., 1997). Different heating times may inflict a different degree of damages on starch granule condition. Heat moisture treatment causes the starch to swell, alters the structure of granules, and leads to deformation of the starch granules because of the rapid processing of heat in a short time (Nadiah et al., 2015). Another study showed that textural changes in cooked sweet potato were related with starch properties, with a high gelatinization percentage and greater water absorption capacity, which led to produce hydrolysis and cell wall solubulization (He et al., 2013). The heatmoisture treatment of starch can cause damage to granular integrity and birefringence losses (Singh et al., 2004). On the other hand, (Zylema et al., 1985) stated that no difference in the swelling of starch granule during microwave and conduction heating at the same heating rate. However, there is considerable varietal variation in the characteristics of potato product texture depending on processing or cooking methods applied (Hassanpanah et al., 2011).

Suitable varieties of high-quality seed potatoes are an essential requirement for profitable and sustainable potato cultivation (NIVAP, 2007) as well as potato products. As a useful solution for long storage and low cost transportation, True Potato Seed (TPS) or the actual 'Botanical potato seed' were introduced to reduce production costs and increase the availability of high quality disease-free tubers without depending on multiplication of seed tuber. However, there are few studies on the properties of tubers produced from TPS as processed potato compared to common potatoes. These studies could allow determining the texture and starch characteristics of different varieties which may contribute valuable information for processed potato products. Therefore, further research needs to be conducted to study the issue of microwave heating on the structure of local seed potato and TPS tubers. The purpose of this study was to clarify how the local potato and TPS tubers change morphologically and physiologically; and how the starch condition of local potato and TPS tubers changes histologically after microwave heating.

\section{MATERIALS AND METHODS}

\section{Plant Material}

The experiment was conducted at two universities in Bangladesh and Japan. In October 2015, potato tubers of True Potato seed (TPS) variety of 'BARI TPS-1' and seed potato varieties of 'Diamant', 'Romana' and 'Tel Pakri' were harvested and collected from Department of Agronomy, Faculty of Agriculture, Sher-eBangla Agricultural University, Bangladesh (Plate 1). Seventy tubers for each cultivar were taken for the experiment. All the materials were of 25-30 days and non-stored tubers. Size, weight, and the specific gravity of all the tubers were measured. This part of the experiment was conducted at the laboratory of the Department of Agronomy, Faculty of Agriculture, She-e-Bangla Agricultural 
University, Bangladesh. Both sides of each potato tuber were cut and a column $(0.5 \mathrm{~cm}$ in diameter $\times 1 \mathrm{~cm}$ in height) from the tuber was drawn out by using a cork borer. The columns were taken for the microwave treatment. The samples were brought to Japan for further analysis. The sample analysis was done at the laboratory of the Department of Bioproduction, Faculty of Agriculture, Yamagata University, Japan.
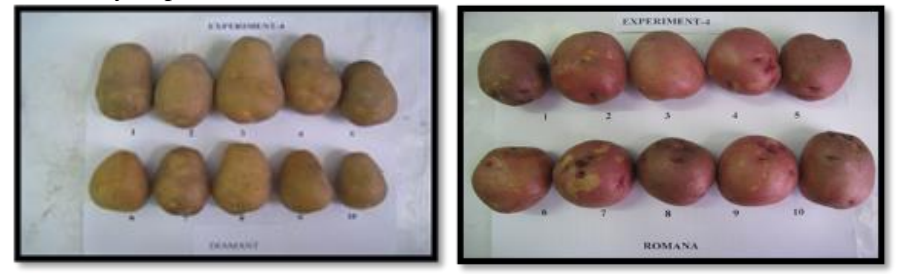

a. Diamant

b. Romana
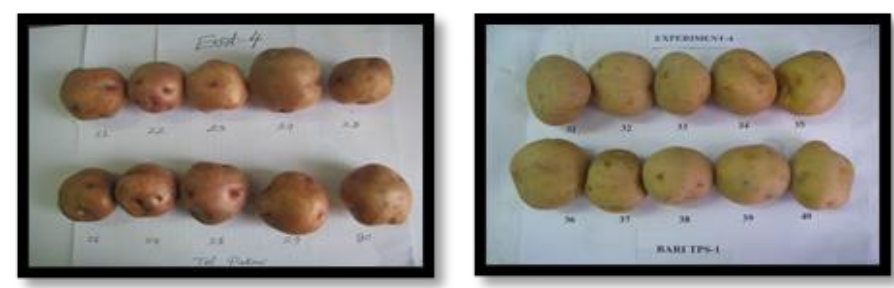

c. Tel Pakri

d. BARI TPS-1

Plate 1 Potato varieties used for microwave heating

\section{Preparation of microwave-treated samples}

Potato column from each cultivar was taken in a container and $50 \mathrm{~mL}$ of water was poured into the container. Each potato column was then treated for 0 (without microwave heating) and 20, 40, 60, 90, 120, 240, and $300 \mathrm{sec}$ microwave heating. Each of the samples was always kept in the same position (center) within the microwave to avoid any change in power absorption. Multiple preliminary tests were conducted to select the conditions required for each treatment following the technique previously prescribed by Palav and Seetharaman (2007).

\section{Water Loss and Hardness Measurement}

Potato columns were weighed before and after the heat treatments for the measurement of water loss or weight loss. Potato firmness was also measured before and after the heat treatments using a Force Gauge equipped with a $5 \mathrm{~mm}$ triangle plunger. The weight loss was expressed by the ratio of the weigh difference between the fresh and treated samples to the original weight. The firmness loss was also expressed by the ratio of shear force difference between the fresh and treated samples to the original shear force.

\section{Histological analysis of starch granule}

Before and after heating by microwave oven three to five cubic samples (approx $5 \mathrm{~mm}$ ) were taken from a few parts of each treated column, and dipped into $5 \mathrm{~mL}$ Formaldehyde-acetic acid alcohol (FAA), and kept at ambient temperature. All of the treated and untreated tuber samples were stored at $-20^{\circ} \mathrm{C}$ and lyophilized. The microstructure of the dried sample was measured by cutting the cubes half longitudinally along the central pith. Small pieces revealing advanced lesion were prepared for Scanning Electronic Microscope (SEM) studies after coating Pt by ion coater. The rest of the dry samples were then crushed and the powder was stored at $-20^{\circ} \mathrm{C}$

\section{Swelling and Solubility}

Swelling and solubility of starch were determined by adopting the method prescribed by Schoch (1964). Approximately $0.5 \mathrm{~g}$ of powdered samples of each treatment were mixed with $25 \mathrm{~mL}$ of distilled water in a centrifuge tube and heated at $85^{\circ} \mathrm{C}$ in a shaking water bath for $30 \mathrm{~min}$. The starch solution was cooled at ambient temperature and then centrifuged (5100 KUBOTA, Tokyo, Japan) for $15 \mathrm{~min}$ at $3500 \mathrm{rpm}$. After centrifugation, the swelling was determined as sediment weight $(\mathrm{g} / \mathrm{g})$, while the supernatant was used for measuring the solubility of starch. The supernatant was carefully decanted to metal crucible dish, and dried overnight at $105^{\circ} \mathrm{C}$ in an oven, and solubility was calculated. The swollen starch sediment in the tube was weighed. Swelling and solubility of the starches were calculated using the following formulae:
Solubility $(\%)=\frac{W_{d}}{W_{\text {s dry basis }}} \times 100$

Where, $\mathrm{W}_{\mathrm{sd}}=$ dried sediment mass, $\mathrm{W}_{\mathrm{s}}=$ original sample weight, $\mathrm{W}_{\mathrm{d}}=$ dried residue.

\section{Statistical analysis}

Data were processed by analysis of variance (ANOVA) and reported as the mean \pm standard error (SE) and multiple comparison tests were by using Tukey's HSD post-hoc test $(p<0.05)$ by using XLSTAT statistical software (version 2016.1).

\section{RESULTS AND DISCUSSION}

Effect of microwave-water treatment on the percentage of potato column weight loss

The percentage of column weight loss of all potato varieties increased continuously throughout the heating treatment. 'BARI-TPS-1' and 'Tel Pakri' showed comparatively faster weight loss percentage than the other two varieties (Figure 1). At $60 \mathrm{sec}$ of heating, columns weight loss of 'BARI-TPS-1' and 'Tel Pakri' reached to $6.89 \%$ and $5.55 \%$ respectively, which is significantly higher than 'Diamant' $(0.94 \%)$ and 'Romana' $(1.24 \%)$, and this tendency continued thereafter. At $90 \mathrm{sec}$ of heating 'BARI-TPS-1' attained 13.69\% weight loss which is significantly higher than other varieties; 'Diamant' (3.3\%) and 'Romana' (7\%), 'Tel Pakri' (7.57\%) (Figure 1). Similarly, at $240 \mathrm{sec}$ of heating column weight loss of 'BARI-TPS-1' reached to $38.04 \%$ weight loss which was significantly higher than other varieties; 'Diamant' $(24.42 \%)$ and 'Romana' (29.58\%), but significantly lower than to 'Tel Pakri' (44.98\%) (Figure 1).

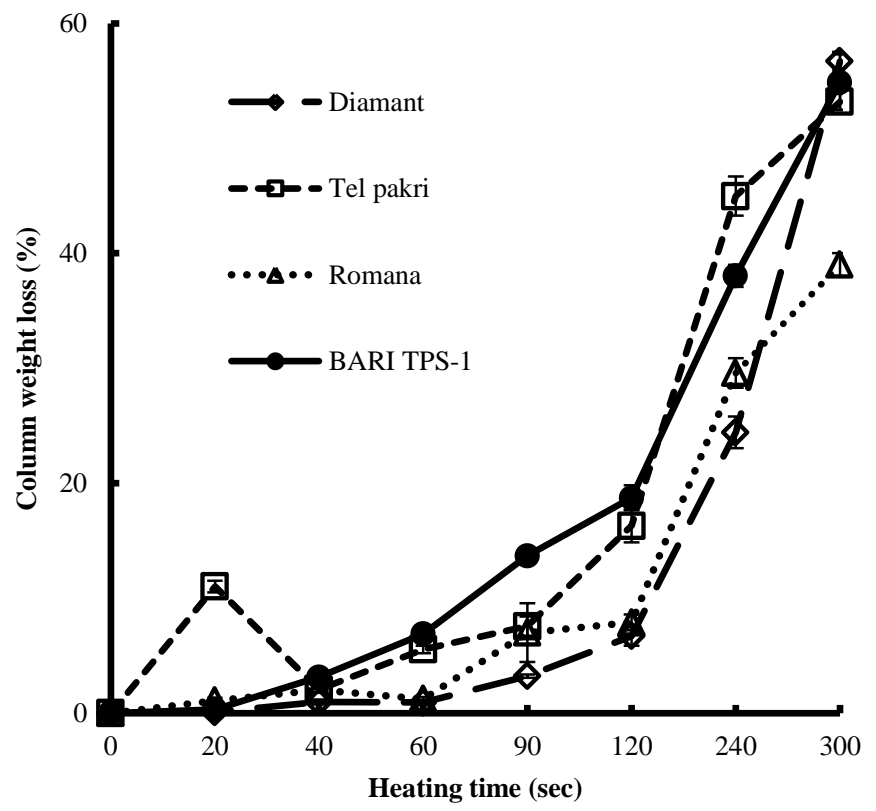

Figure 1 Effect of microwave heating on percentage potato column weight loss for a different period. Vertical bars indicate the standard error of the means $(n=$ $10 \pm \mathrm{SE})$.

Effect of microwave-water treatment on the percentage of potato column firmness loss

Although the percentage of firmness losses of all potato varieties increased continuously throughout heating treatment, BARI-TPS-1' showed more rapid firmness loss percentage compared to other potato varieties (Figure 2). At $60 \mathrm{sec}$ of heating firmness loss of BARI TPS-1 reached to $83.17 \%$ which was significantly higher than other varieties 'Diamant' (20.88\%), 'Romana' (45.47\%) and 'Tel Pakri' $(26.06 \%)$ (Figure 2), and this tendency continued thereafter. At $90 \mathrm{sec}$ of heating, 'BARI TPS-1' attained $93.41 \%$ firmness loss which was also significantly higher than other varieties 'Diamant' $(44.06 \%)$ and 'Romana' $(47.73 \%)$, 'Tel Pakri' $(74,14 \%)$ (Figure 2) and stayed constant until $300 \mathrm{sec}$ of microwave heating. The other three varieties attained approximately $90 \%$ firmness losses after $240 \mathrm{sec}$ of microwave heating and remained constant after $300 \mathrm{sec}$ of microwave treatment (Figure 2)
Swelling $(g / g)=\frac{W_{\text {sd }}}{W_{\text {sdry basis }}} \ldots$ 


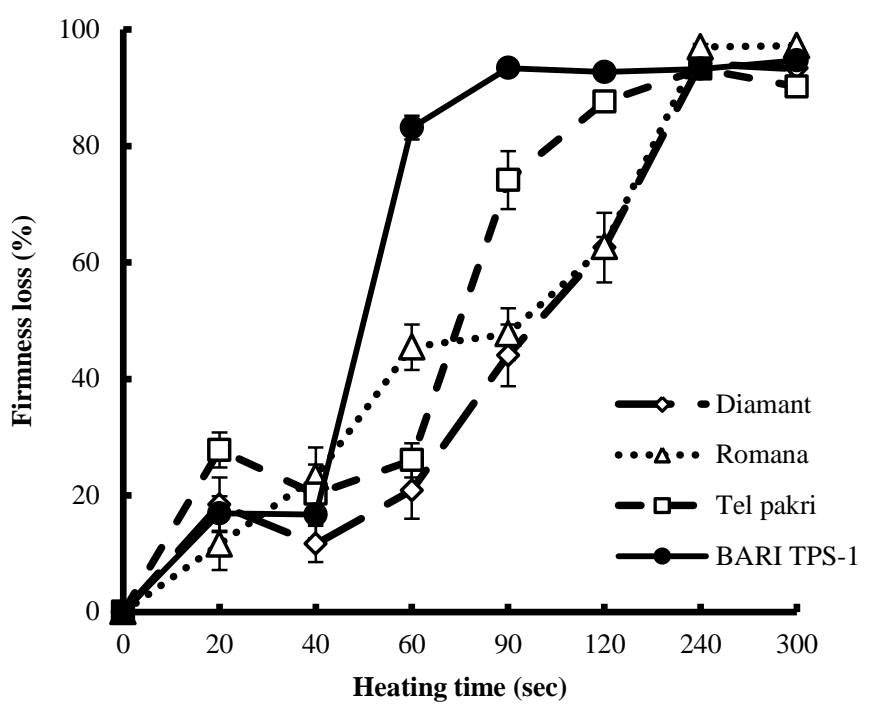

Figure 2 Effect of microwave heating on percentage potato column firmness loss for a different period. Vertical bars indicate the standard error of the means $(n=$ $10 \pm \mathrm{SE})$.

The rapid weight losses and firmness losses of potato columns after microwave water treatment for a different period are presented in Figure 1 and 2. Microwave treatment of potato cube promotes weight loss caused by combined loss of weight and dry matter (Severini et al., 2003). Blaszczak et al. (2004) also reported 19$23 \%$ weight loss due to microwave treatment in transgenic potatoes. In this experiment, BARI TPS-1 and Tel Pakri potato column showed a comparatively higher rate of weight loss and firmness loss percentage than other cultivars (Figure 1 and 2). This implies that these two cultivars might obtain gelatinization temperature with a shorter period of heating in the microwave (Kaur et al., 2002). Microwaved cooking of potato for $4 \mathrm{~min}$ resulted in rapid weight loss in tuber; they also reported softening of starchy tubers after microwaving (Ibrahim et al., 2012). However, softness or firmness did not reply to temperature solely with microwave heating. The softening of potato tissue indicated the degradation of the cell wall structure and middle lamella and starch gelatinization because of heating (Bordoloi et al., 2012).

Effect of microwave-water treatment on potato column swelling and solubility

A significant increase was observed in swelling power for all potato column starches after heating with water. Swelling capacity started to increase after 60 sec of heating in all four varieties and maintained a similar pattern of swelling thereafter (Figure 3). When microwave heating was applied, water absorption and heating caused the water molecules to enter into the starch granule and cause swelling of granules (Zhu, 2015). The disrupted hydrogen bonds with the exposed hydroxyl groups of amylose and amylopectin cause swelling of the starch granule during thermal gelatinization (Charles et al., 2016).

Comparatively stabilized swelling capacity after $90 \mathrm{sec}$ heating (Figure 4) might be due to rapid temperature rise and high retention of water that entered the granule, resulting in a high swelling capacity, which induced packing of gelatinized starch granules (Sjoo et al., 2009). The rapid increase of swelling power was reported in corn starches after heat-moisture-treatment between 65 and $75^{\circ} \mathrm{C}$ temperature, followed by a slow or almost constant swelling rate above $75-80^{\circ} \mathrm{C}$ (Iromidayo et al., 2010). Similarly, an observation was reported by Barminas et al. (2008). At higher temperature starches tend to lose their granular structure resulting in lower water binding capacity which leads to lower swelling capacity (Barminas et al., 2008; Alam and Hasnain, 2009). This can also be explained by the observation of Demiate $\boldsymbol{e t}$ al. (2011), who indicated that when Starch granules swell to the peak value the swollen granules disintegrate to leach out starch molecules out of the granules and led to increase solubility.

In this study, starch Solubility started to increase significantly after $60 \mathrm{sec}$ of microwave heating and rapidly increased thereafter in all varieties (Figure 3). Percentage of solubility was higher in 'BARI TPS-1' $(21.61 \%)$ than other varieties; 'Diamant' (16.33\%), 'Romana (19\%) and 'Tel Pakri (14.94\%) after 60 sec of microwave heating and rapidly increased thereafter for 90 to $300 \mathrm{sec}$ of heating, resulting in a significant difference with other varieties (Figure 3). Thus, microwave treated starch of 'BARI TPS-1' was more soluble compared to the other local potato varieties. Solubility represents the amount of solubilized starch molecules at a certain temperature. The loss of granular structure at higher temperatures increases the solubility of starch. Alam and Hasnain (2009) reported similar results on taro starch.

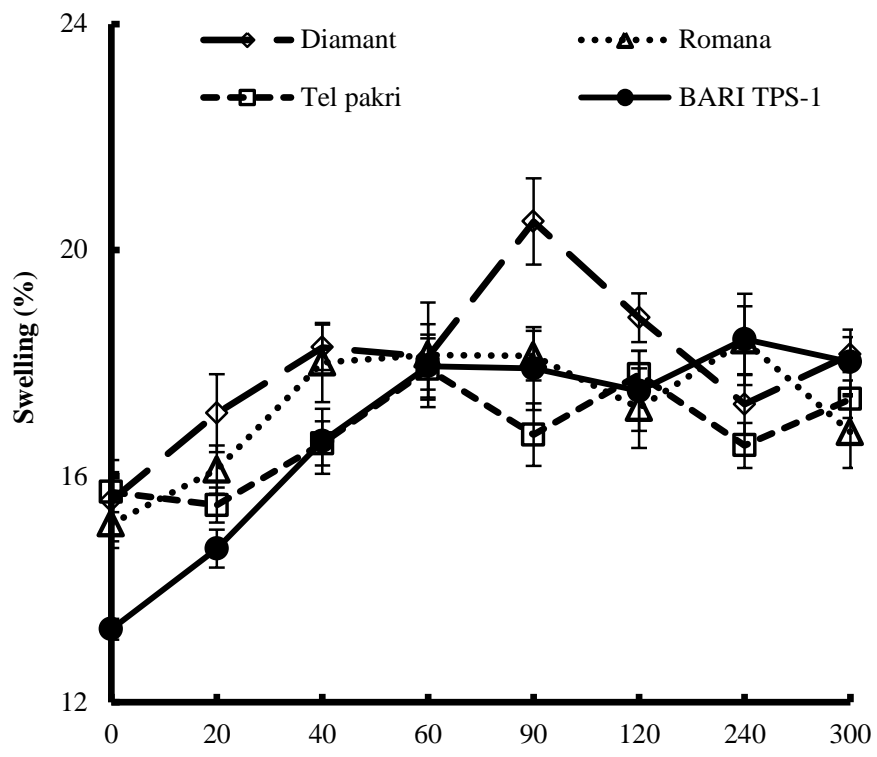

Heating time (sec)

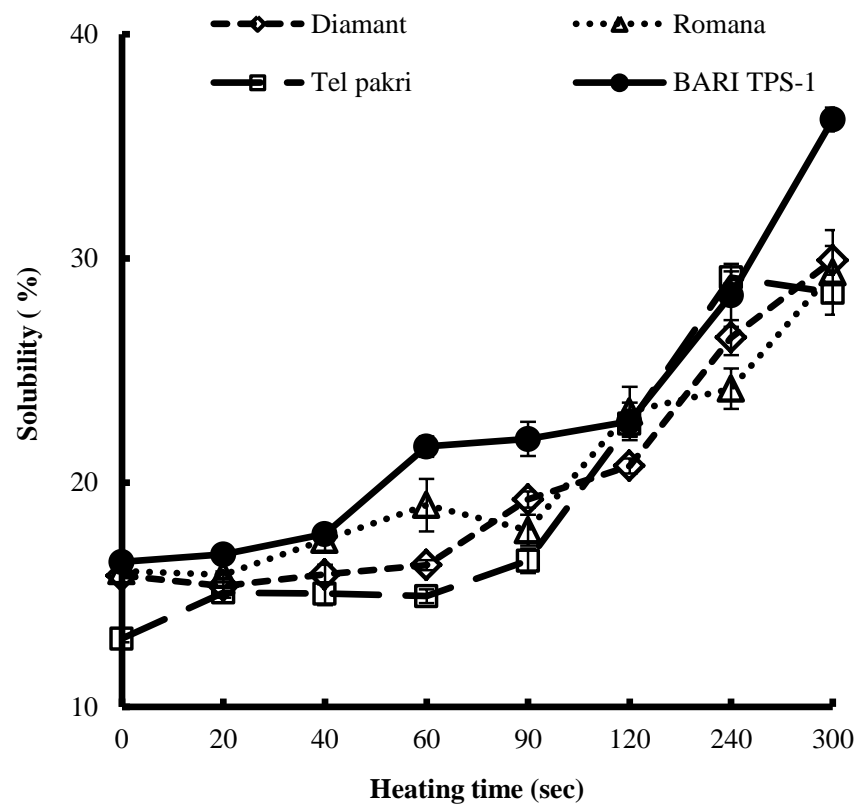

Figure 3. Effect of microwave heating on potato column swelling and solubility for a different period. Vertical bars indicate the standard error of the means $(\mathrm{n}=$ $10 \pm \mathrm{SE})$.

A significant reduction of solubility in potato starch granules after microwave heating in water suspension was observed by Ma et al. (2015). However, this study resulted in an increase in solubility of potato columns after microwavewater treatment for the different periods. Starches treated after 90 to $300 \mathrm{sec}$ of microwave heating with water were more soluble compared to other treatments (Figure 3 ). This could be explained by the prolonged heating time on starches which led to the loss of granular structure and release of amylase fraction caused by weaker inter- and intramolecular hydrogen bonds after heat-moisture treatments (Lawal, 2009). As heating continued, the mobility and collision of starch granules increased and amylose molecule leached out resulting in enhanced solubility (Sodhi and Singh, 2003).

In the present study also showed comparatively higher solubility percentage in 'BARI TPS-1' tuber than the other local varieties. Solubility is determined by the amylose content and swelling power by amylopectin (Ritika et al., 2010). The high solubility in TPS variety could be affected by the loosely held granule structure and low molecular weight amylose which resulted in leaching out of an amorphous portion of starch granule (Nwokocha et al., 2009).

\section{Changes of potato columns after microwave heating}

Representative potato columns from each variety after microwave treatment for the different periods $(0,60,90,120,240$, and $300 \mathrm{sec}$ ) are shown in (Plate 2 and 3 ). The changes of potato column from each variety after each microwave treatment are summarized in Table 1. Textural changes of potato columns were observed throughout the different periods of the microwave treatment. After 60 
sec of microwave heating, all of the potato samples started to show slight depression. A decrease in brightness and increase in yellowness were also observed in all the heat-treated potato columns (Plate 2 and 3); and brownish appearance on 'BARI TPS-1'column might imply triggering of enzymatic browning (Severini et al., 2003). This immediate weakening potato sample tissue after microwave heating might occur due to swelling of gelatinized starch (Wang et al., 2010).
As the treatment continued for $90,120,240$, and $300 \mathrm{sec}$, all the potato column samples eventually obtained noticeable ruptured structure and central depression, but 'BARI TPS-1' column showed visible central depression and slightly brownish appearance after $90 \mathrm{sec}$ of heating which is faster than other potato varieties (Plate 2 and 3 ).

Table 1 Changes of potato columns after microwave treatment

\begin{tabular}{|c|c|c|c|c|c|c|}
\hline \multirow{2}{*}{ Variety } & \multicolumn{6}{|c|}{ Heating time (sec) } \\
\hline & $\mathbf{0}$ & 60 & 90 & 120 & 240 & 300 \\
\hline Diamant & $\begin{array}{l}\text { Uniform } \\
\text { sized } \\
\text { column }\end{array}$ & $\begin{array}{l}\text { Color changed in the } \\
\text { center portion, became } \\
\text { less bright, }\end{array}$ & $\begin{array}{l}\text { Color changed in the } \\
\text { center portion, slight } \\
\text { yellowness }\end{array}$ & $\begin{array}{l}\text { Color changed in center } \\
\text { portion gave the } \\
\text { yellowish appearance }\end{array}$ & $\begin{array}{c}\text { Slightly ruptured from } \\
\text { center depression } \\
\text { visible }\end{array}$ & $\begin{array}{l}\text { Ruptured from the side, } \\
\text { center depression, } \\
\text { mostly deformed }\end{array}$ \\
\hline Romana & $\begin{array}{l}\text { Uniform } \\
\text { sized } \\
\text { column }\end{array}$ & $\begin{array}{l}\text { Became less bright, } \\
\text { Slight depression } \\
\text { visible in the center } \\
\text { portion }\end{array}$ & $\begin{array}{l}\text { Slight depression visible, } \\
\text { slightly yellowish }\end{array}$ & $\begin{array}{l}\text { central portion became } \\
\text { yellowish, slightly } \\
\text { center depression }\end{array}$ & $\begin{array}{l}\text { Ruptured from the } \\
\text { side, slight center } \\
\text { depression }\end{array}$ & $\begin{array}{c}\text { Ruptured from the side, } \\
\text { slight center } \\
\text { depression, mostly } \\
\text { deformed }\end{array}$ \\
\hline Tel Pakri & $\begin{array}{l}\text { Uniform } \\
\text { sized } \\
\text { column }\end{array}$ & $\begin{array}{c}\text { center portion gave the } \\
\text { yellowish appearance, } \\
\text { slight center } \\
\text { depression }\end{array}$ & $\begin{array}{l}\text { Color changed in the } \\
\text { center portion and became } \\
\text { more yellowish }\end{array}$ & $\begin{array}{l}\text { Depressed center region } \\
\text { visible, started to } \\
\text { deform, slightly } \\
\text { brownish appearance }\end{array}$ & $\begin{array}{l}\text { Ruptured from the } \\
\text { side, slightly center } \\
\text { depression, mostly } \\
\text { deformed }\end{array}$ & $\begin{array}{c}\text { Ruptured from the side, } \\
\text { slight center } \\
\text { depression, mostly } \\
\text { deformed }\end{array}$ \\
\hline BARI TPS-1 & $\begin{array}{l}\text { Uniform } \\
\text { sized } \\
\text { column }\end{array}$ & $\begin{array}{c}\text { Columns started to } \\
\text { show yellowness, } \\
\text { center depression } \\
\text { visible }\end{array}$ & $\begin{array}{l}\text { Columns had a brownish } \\
\text { appearance, center } \\
\text { depression visible }\end{array}$ & $\begin{array}{c}\text { Center depression and } \\
\text { brownish appearance in } \\
\text { color }\end{array}$ & $\begin{array}{l}\text { Center depression, } \\
\text { ruptured side regions }\end{array}$ & $\begin{array}{c}\text { Ruptured from the side, } \\
\text { prominent center } \\
\text { depression, mostly } \\
\text { deformed }\end{array}$ \\
\hline
\end{tabular}

Table 2 Changes of potato column structures after microwave treatment

\begin{tabular}{|c|c|c|c|c|c|c|c|c|}
\hline \multirow{2}{*}{ Variety } & \multicolumn{8}{|c|}{ Heating time (sec) } \\
\hline & $\mathbf{0}$ & 20 & 40 & 60 & 90 & 120 & 240 & 300 \\
\hline Diamant & $\begin{array}{l}\text { Small } \\
\text { individual } \\
\text { granules }\end{array}$ & $\begin{array}{c}\text { Mostly } \\
\text { individual } \\
\text { small } \\
\text { granules } \\
\end{array}$ & $\begin{array}{l}\text { Small to } \\
\text { medium } \\
\text { swollen } \\
\text { granules }\end{array}$ & $\begin{array}{l}\text { Cell wall started to } \\
\text { rupture, small to medium } \\
\text { swollen granules }\end{array}$ & $\begin{array}{l}\text { Swollen } \\
\text { clustered } \\
\text { granules }\end{array}$ & $\begin{array}{l}\text { Cell wall } \\
\text { ruptured, } \\
\text { clumped region }\end{array}$ & $\begin{array}{l}\text { Irregular, } \\
\text { swollen } \\
\text { granule } \\
\text { visible }\end{array}$ & $\begin{array}{l}\text { Ruptured from the } \\
\text { side, center } \\
\text { depression, } \\
\text { mostly deformed }\end{array}$ \\
\hline Romana & $\begin{array}{l}\text { Small } \\
\text { individual } \\
\text { granules }\end{array}$ & $\begin{array}{c}\text { Small } \\
\text { individual } \\
\text { granules }\end{array}$ & $\begin{array}{c}\text { Mostly } \\
\text { individual } \\
\text { small } \\
\text { granules, } \\
\text { slightly } \\
\text { swollen }\end{array}$ & $\begin{array}{l}\text { Medium to large swollen } \\
\text { granules }\end{array}$ & $\begin{array}{l}\text { Ruptured cell } \\
\text { wall no } \\
\text { individual } \\
\text { granule }\end{array}$ & $\begin{array}{l}\text { Color change in } \\
\text { the central } \\
\text { portion, slightly } \\
\text { center } \\
\text { depression }\end{array}$ & $\begin{array}{l}\text { Ruptured, } \\
\text { clumped } \\
\text { region }\end{array}$ & $\begin{array}{l}\text { Gelatinized, small } \\
\text { intercellular space }\end{array}$ \\
\hline Tel Pakri & $\begin{array}{l}\text { Small } \\
\text { individual } \\
\text { granules }\end{array}$ & $\begin{array}{l}\text { Mostly } \\
\text { individual } \\
\text { small } \\
\text { granule }\end{array}$ & $\begin{array}{l}\text { Swollen, } \\
\text { medium to } \\
\text { large } \\
\text { clumped } \\
\text { granules }\end{array}$ & $\begin{array}{l}\text { Cell wall ruptured, small } \\
\text { to medium clumped } \\
\text { granules }\end{array}$ & $\begin{array}{l}\text { Large, } \\
\text { swollen, cell } \\
\text { cluster }\end{array}$ & $\begin{array}{l}\text { Ruptured, } \\
\text { clumped region }\end{array}$ & $\begin{array}{l}\text { Ruptured, } \\
\text { clumped } \\
\text { region }\end{array}$ & $\begin{array}{l}\text { Gelatinized, small } \\
\text { intercellular space }\end{array}$ \\
\hline $\begin{array}{l}\text { BARI } \\
\text { TPS-1 }\end{array}$ & $\begin{array}{l}\text { Small } \\
\text { individual } \\
\text { granules }\end{array}$ & $\begin{array}{l}\text { Mostly } \\
\text { individual } \\
\text { small } \\
\text { granules }\end{array}$ & $\begin{array}{l}\text { Swollen } \\
\text { clustered } \\
\text { granules }\end{array}$ & $\begin{array}{l}\text { Cell wall completely } \\
\text { ruptured, individual } \\
\text { granules no longer visible }\end{array}$ & $\begin{array}{l}\text { Ruptured, } \\
\text { clumped } \\
\text { region }\end{array}$ & $\begin{array}{l}\text { Ruptured, } \\
\text { clumped region }\end{array}$ & $\begin{array}{l}\text { Clumped, } \\
\text { slightly } \\
\text { gelatinized } \\
\text { regions }\end{array}$ & $\begin{array}{l}\text { Gelatinized, no } \\
\text { intercellular space }\end{array}$ \\
\hline
\end{tabular}

\section{Changes of potato column structure after microwave heating}

Plate 4 and 5 are represented the SEM images of changes in the structure of starch granule due to microwave treatment. Liu et al. (2012) also observed structural change of potato starch granule after microwave heating. The changes in potato column structure from each variety after each microwave treatment are summarized in Table 2.

After $40 \mathrm{sec}$ of microwave heating more or less all of the potato samples started to show individual compacted granules (Plate 4). This deformation occurred progressively until the starch granules were almost completely ruptured from 60 to $300 \mathrm{sec}$ of microwave treating in all potato samples. A similar observation was reported by Palav and Seetharaman (2007), which showed a gradual deformation of starch granule structure from 0 to $15 \mathrm{sec}$ by microwave heating. However, 'BARI TPS-1' was intended to obtain clumped and ruptured starch granule more rapidly than other potato variety, and started to show clumped and ruptured granules after only 60 and $90 \mathrm{sec}$ of heating (Plate 4 and 5). Studies showed that microwave heating can cause total disruption of potato starch granule by affecting the water molecules presented in the crystalline region and promote deformation (Karakkainen et al., 2011; Fan et al., 2014).

In this study, different potato varieties showed different swelling and deformation pattern at different heating times. This might suggest different microwave heating patterns and temperature gradient and different time regimes (Xie et al., 2013). Xie et al. (2013) also reported that after $15 \mathrm{sec}$ of heating with $80^{\circ} \mathrm{C}$ fina temperature showed surface fractures and deformation, further $20 \mathrm{sec}$ of heating with $95^{\circ} \mathrm{C}$ final temperature showed heavily deformed and collapsed starch granule. However, the least consistency in TPS starch granules structure compared to other varieties probably indicated accelerated gelatinization of TPS starch granules after microwave heating (Severini et al., 2005). 'Tel Pakri' variety showed slightly similar starch granule deformation with the 'BARI-TPS 1 'variety after 120 and $240 \mathrm{sec}$ of heating (Plate 5). 


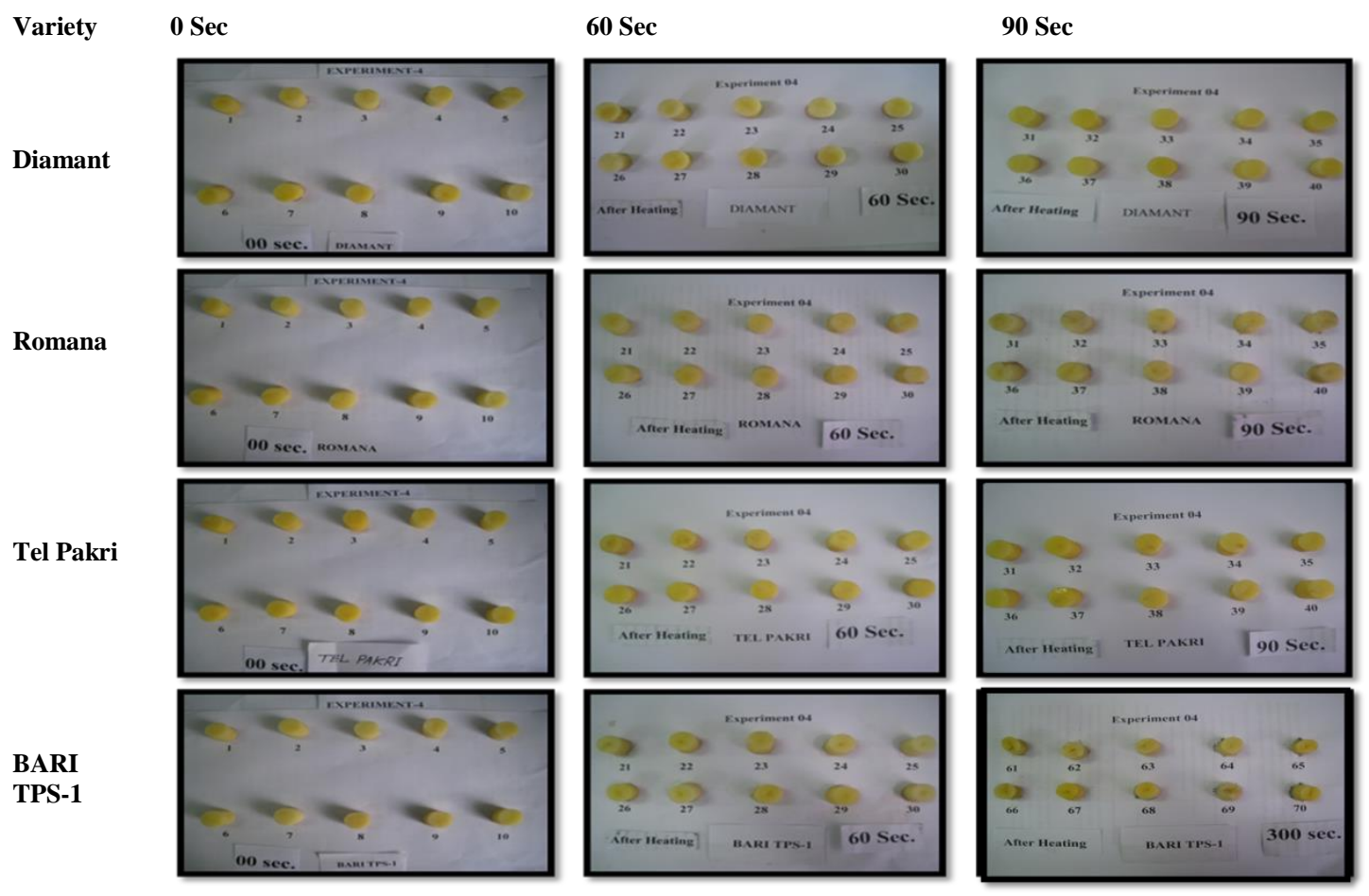

Plate 2 Images of potato columns after microwave treatment for 0,60 and $90 \mathrm{sec}$

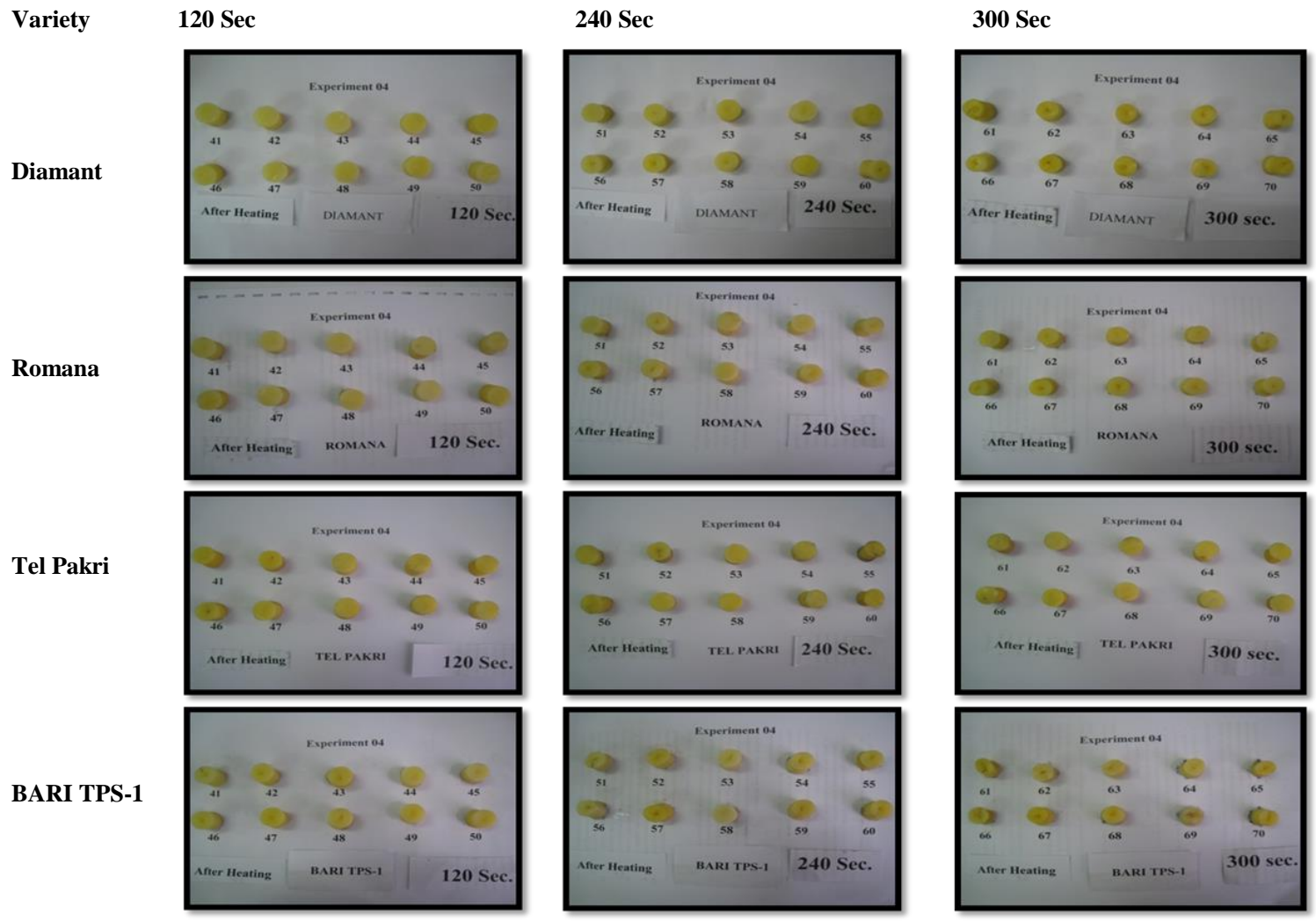

Plate 3 Images of potato columns after microwave treatment for 120, 240 and $300 \mathrm{sec}$ 

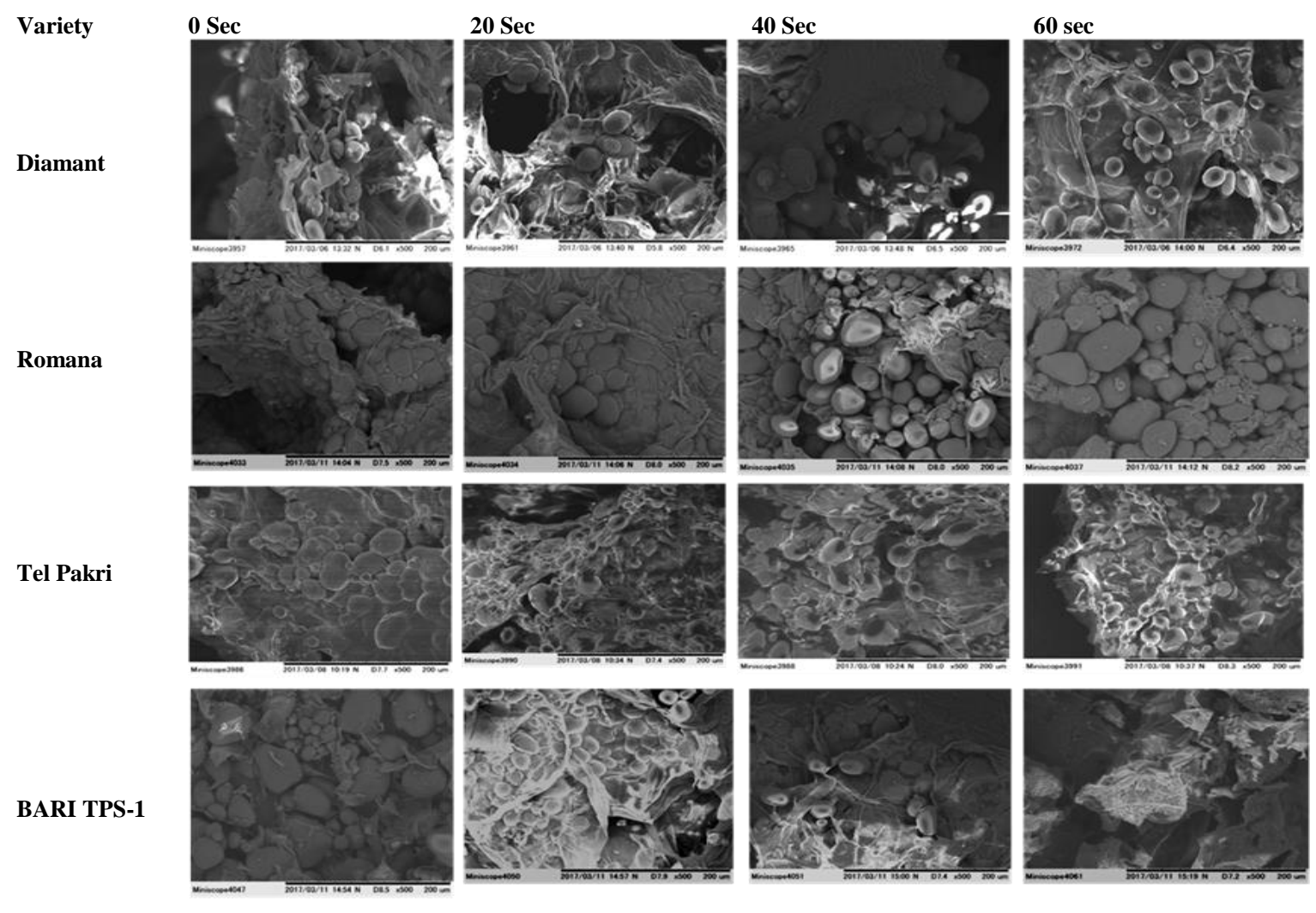

Plate 4 SEM Images of cross-sections of microwave heated potato columns for 0, 20, 40 and $60 \mathrm{sec}$
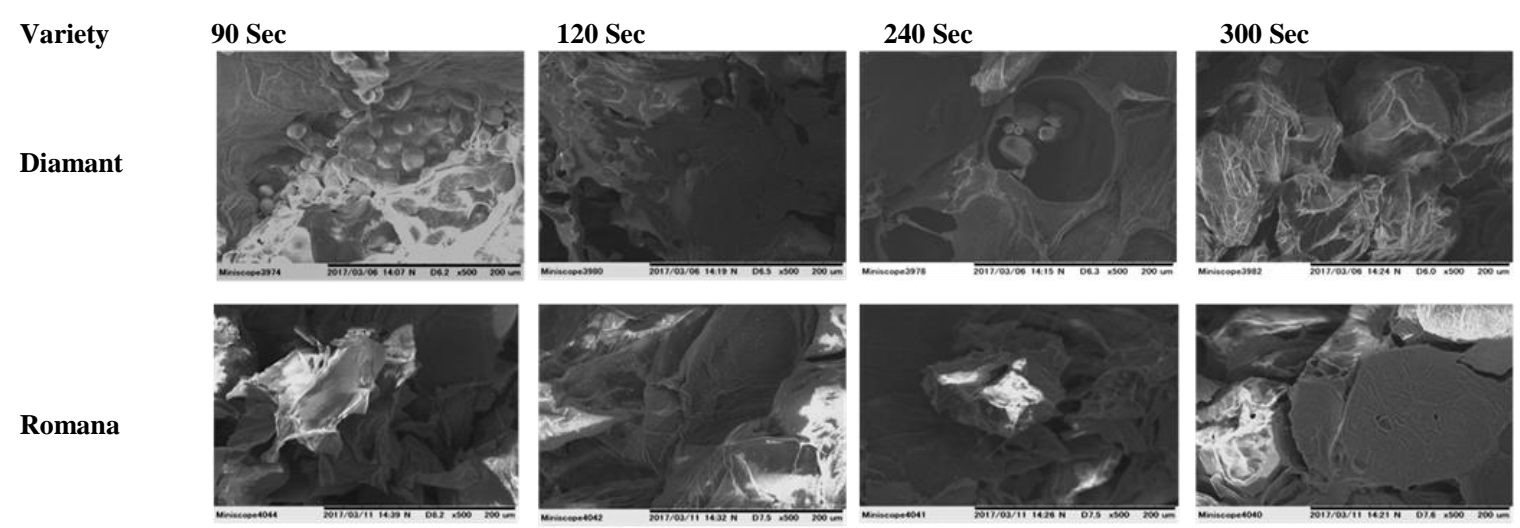

Tel Pakri
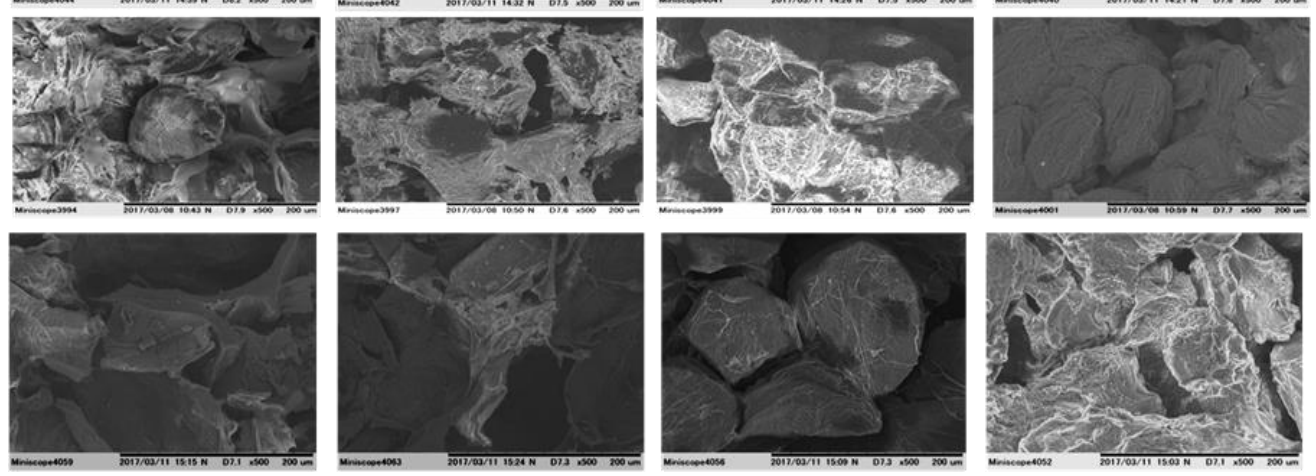

Plate 5 SEM Images of cross-sections of microwave heated potato columns for 90, 120, 240 and $300 \mathrm{sec}$

\section{CONCLUSION}

The microwave heating with water for a different period affected the treated potato tubers and resulted in some considerable changes. The 'BARI TPS-1' tuber column had comparatively higher weight loss and firmness loss percentages, which indicated a faster heating rate in TPS tuber and also softer texture compared to the other local varieties. The 'Tel Pakri' potato tuber showed slightly similar properties with the TPS compared to the other local tubers The Higher solubility percentage in 'BARI TPS-1' column also implied rapid leach out of starch molecules and forming of a network that held water and form gelatinized structure. Therefore, TPS tuber may acquire pasting temperature within a shorter heating period, suggesting as an option for using as cooking potato products like mash potato, potato puree, or as a salad. However, it can be said that different potato varieties may achieve different quality parameters. As potato is widely consumed and processed in home and industries, further studies on quality attributes and tuber processing techniques may help to understand the potentiality of independent potato tubers or cultivars in potato tuber processing. 


\section{REFERENCES}

Alam, F., \& Hasnain, A. (2009). Studies on Swelling and Solubility of Modified Starch from Taro (Colocasia esculenta): Effect of $\mathrm{pH}$ and Temperature. Agriculturae Conspectus Scientificus, 74(1), 45-50. Available: https://hrcak.srce.hr/35776

Barminas, J., Onen, A., Williams, E., Zaruwa, M., Mamuru, S., \& Haggai, D. (2008). Studies on functional properties of borassus starch from fresh germinating nuts of giginya (Borassus aethiopum) palm. Food Hydrocolloids, 22(2), 298-304.https://dx.doi.org/ 10.1016/j.foodhyd.2006.11.018

Błaszczak, W., Sadowska, J., Fornal, J., Vacek, J., Flis, B., \& Zagórski-Ostoja W. (2004). Influence of cooking and microwave heating on microstructure and mechanical properties of transgenic potatoes. Nahrung/Food, 48(3), 169 176.https://dx.doi.org/10.1002/food.200300436

Bondaruk, J., Markowski, M., \& Błaszczak, W. (2007). Effect of drying conditions on the quality of vacuum-microwave dried potato cubes. Journal of Food Engineering, 81(2)

312.http://dx.doi.org/10.1016/j.jfoodeng.2006.10.028

Bordoloi, A., Singh, J., \& Kaur, L. (2012). In vitro digestibility of starch in cooked potatoes as affected by guar gum: Microstructural and rheological characteristics. Food Chemistry, 12061213.https://dx.doi.org/10.1016/i.foodchem.2012.01.063

Charles, A. L., Cato, K., Huang, T.-C., Chang, Y.-H., Ciou, J.-Y., Chang, J.-S., \& Lin, H.-H. (2016). Functional properties of arrowroot starch in cassava and sweet potato composite starches. Food Hydrocolloids, 53, 187 191.https://dx.doi.org/10.1016/j.foodhyd.2015.01.024

Collins, J. L., \& McCarthy, I. E. (1969). Comparison of microwave energy with boiling water for blanching whole potatoes. Food Technology. 23(3), 63-66.

Demiate, I. M., \& Kotovicz, V. (2011). Cassava starch in the Brazilian food industry. Ciência e Tecnologia de Alimentos, 31(2), 388-397. https://dx.doi.org/10.1590/s0101-20612011000200017

Fan, D., Wang, L., Chen, W., Ma, S., Ma, W., Liu, X., \& Zhang, H. (2014) Effect of microwave on lamellar parameters of rice starch through small-angle Xray scattering. Food Hydrocolloids, 35, 620626.https://dx.doi.org/10.1016/j.foodhyd.2013.08.003

Hassanpanah, D., Hassanabadi, H., \& Azizi Chakherchaman, S. H. (2011) Evaluation of Cooking Quality Characteristics of Advanced Clones and Potato Cultivars. American Journal of Food Technology, 6(1), 7279.http://dx.doi.org/10.3923/ajft.2011.72.79

He, J., Cheng, L., Gu, Z., Hong, Y., \& Li, Z. (2013). Effects of low-temperature blanching on tissue firmness and cell wall strengthening during sweet potato flour processing. International Journal of Food Science \& Technology, 49(5), 1360-1366.https://dx.doi.org/10.1111/ijfs.12437

Huang, J., Hess, W. M., \& Weber, D. J. (1990). Scanning electron microscopy: Tissue characteristics and starch granule variations of potatoes after microwave $\begin{array}{llll}\text { and conductive heating. Food Structure, 9, } 113 & -\end{array}$ 122.http://digitalcommons.usu.edu/foodmicrostructure/vol9/iss2/7

Ibrahim, G. E., El-Ghorab, A. H., El-Massry, K. F., \& Osm, F. (2012). Effect of Microwave Heating on Flavour Generation and Food Processing. The Development and Application of Microwave Heating.http://dx.doi.org/10. 5772/49935

Iromidayo, B. O., Adeniyi, T.A. \& Kayode, O. A. (2010). Effect of heat moisture treatment on the functional and tabletting properties of corn starch. African Journal of Pharmacy and Pharmacology, 4, 498-510.

Kärkkäinen, J., Lappalainen, K., Joensuu, P., \& Lajunen, M. (2011). HPLC ELSD analysis of six starch species heat-dispersed in [BMIM]Cl ionic liquid. Carbohydrate Polymers, $84(1)$

509

516.http://dx.doi.org/10.1016/j.carbpol.2010.12.011

Kaur, L., Singh, N., Sodhi, N. S. \& Gujral, H. S. (2002). Some properties of potatoes and their starches I. Cooking, textural and rheological properties of potatoes. Food Chemistry, 79(2), 177-181.https://dx.doi.org/10.1016/s03088146(02)00129-2

Lawal, O. S. (2004). Composition, physicochemical properties and retrogradation characteristics of native, oxidized and acetylated and acid-thinned new cocoyam (Xanthosoma sagittifolium) starch. Food Chemistry, 87, 205-218. http://dx.doi.org/10.1016/j.foodchem.2003.11.013

Lawal, O. S. (2009). Starch hydroxyalkylation: Physicochemical properties and enzymatic digestibility of native and hydroxypropylated finger millet (Eleusine coracana) starch. Food Hydrocolloids, 23(2), 415425.https://dx.doi.org/10.1016/j.foodhyd.2008.02.013

Lewandowicz, G., Fornal, J., \& Walkowski, A. (1997). Effect of microwave radiation on physico-chemical properties and structure of potato and tapioca starches. Carbohydrate Polymers, 34(4), 213 220.http://dx.doi.org/10.1016/s0144-8617(97)00091-x

Liu, J., Ming, J., Li, W., \& Zhao, G. (2012). Synthesis, characterisation and in vitro digestibility of carboxymethyl potato starch rapidly prepared with microwave-assistance. Food Chemistry, 133(4), 1196 1205.http://dx.doi.org/10.1016/i.foodchem.2011.05.061

Ma, S., Fan, D., Wang, L., Lian, H., Zhao, J., Zhang, H., \& Chen, W. (2015). The impact of microwave heating on the granule state and thermal properties of potato $\quad$ starch. Starch -
398.http://dx.doi.org/10.1002/star.201400154

Maragoni, A. G., \& Yada, R. Y. (1994). Building a better potato chips. Agricultural Food Research, 17, 7-11.

Nadiah, N. I., Uthumporn, U., \& Syahariza, Z. A. (2015). Effect of Microwave Heating on Potato and Tapioca Starches in Water Suspension. International Journal on Advanced Science, Engineering and Information Technology. 4(5), 264-271.http://dx.doi.org/10.18517/ijaseit.5.4.502

NIVAP, (2007). Netherlands catalogue of potato varieties. Peeten HMG, Folkertsma S, Schipper JK, Baarveld HR, Klein S (eds). NIVAP, Den Haag, Netherlands. Available: www.nivap.nl

Nwokocha, L. M., Aviara, N. A., Senan, C., \& Williams, P. A. (2009). A comparative study of some properties of cassava (Manihot esculenta, Crantz) and cocoyam (Colocasia esculenta, Linn) starches. Carbohydrate Polymers, 76(3), 362-367. https://dx.doi.org/10.1016/j.carbpol.2008.10.034

Orsat, V., Raghavan, V., \& Meda, V. (2005). Microwave technology for food processing: an overview. The Microwave Processing of Foods, 105118.https://dx.doi.org/10.1533/9781845690212.2.105

Palav, T., \& Seetharaman, K. (2007). Impact of microwave heating on the physico-chemical properties of a starch-water model system. Carbohydrate Polymers, 67(4), 596-604.https://dx.doi.org/10.1016/j.carbpol.2006.07.006

Ritika, B. Y., Khatkar, B. S., \& Yadav, B. S. (2010). Physicochemical, Morphological, Thermal and Pasting Properties of Starches Isolated from Rice Cultivars Grown in India. International Journal of Food Properties. 13(6), 13391354.https://dx.doi.org/10.1080/10942910903131407

Sadowska, J., Vacek, J., Fornal, J., \& Zagórski-Ostoja, W. (2005). Effect of antiviral genetical modification on softening of potato tubers during cooking. European Food Research and Technology, 221(3-4), 336 341.https://dx.doi.org/10.1007/s00217-005-1173-9

Schoch, T. J. (1964). Swelling Power and Solubility of Granular Starches. In: Methods in carbohydrate chemistry, 4, 106-108.

Severini, C., Baiano, A., \& Pilli, T. D. (2003). Microwave blanching of cubed potatoes. Journal of Food Processing and Preservation, 27(6), 475491.https://dx.doi.org/10.1111/j.1745-4549.2003.tb00531.x

Severini, C., Baiano, A., De Pilli, T., Carbone, B. F., \& Derossi, A. (2005). Combined treatments of blanching and dehydration: study on potato cubes. Journal of Food Engineering, 68(3), 289296.https://dx.doi.org/10.1016/j.jfoodeng.2004.05.045

Singh Sodhi, N., \& Singh, N. (2003). Morphological, thermal and rheological properties of starches separated from rice cultivars grown in India. Food Chemistry, 80(1), 99-108.https://dx.doi.org/10.1016/s0308-8146(02)00246-7

Singh, N., Singh Sandhu, K., \& Kaur, M. (2004). Characterization of starches separated from Indian chickpea (Cicer arietinum L.) cultivars. Journal of Food Engineering, 63(4), 441-449.https://dx.doi.org/10.1016/j.jfoodeng.2003.09.003 Sjoo, M. E., Eliasson, A. C., \& Autio, K. (2009). Comparison of different microscopic methods for the study of starch and other components within potato cells. Food, 3 (1), 39-44.

Vadivambal, R., \& Jayas, D. S. (2008). Non-uniform Temperature Distribution During Microwave Heating of Food Materials-A Review. Food and Bioprocess Technology, 3(2), 161-171.https://dx.doi.org/10.1007/s11947-008-0136-0

Vollmer, M. (2003). Physics of the microwave oven. Physics Education, 39(1), 74-81.https://dx.doi.org/10.1088/0031-9120/39/1/006

Wang, R., Zhang, M., \& Mujumdar, A. S. (2010). Effect of Osmotic Dehydration on Microwave Freeze-Drying Characteristics and Quality of Potato Chips. Drying Technology, 28(6), 798 806.https://dx.doi.org/10.1080/07373937.2010.482700

Wilson, W., MacKinnon, I., \& Jarvis, M. (2002). Transfer of heat and moisture during microwave baking of potatoes. Journal of the Science of Food and Agriculture, 82(9), 1070-1073. https://dx.doi.org/10.1002/jsfa.1129

Xie, Y., Yan, M., Yuan, S., Sun, S., \& Huo, Q. (2013). Effect of microwave treatment on the physicochemical properties of potato starch granules. Chemistry Central Journal, 7(1).http://dx.doi.org/10.1186/1752-153x-7-113

Yang, Y., Achaerandio, I., \& Pujolà, M. (2016). Effect of the intensity of cooking methods on the nutritional and physical properties of potato tubers. Food Chemistry, 197, 1301-1310.https://dx.doi.org/10.1016/j.foodchem.2015.11.028

Zhu, F. (2015). Composition, structure, physicochemical properties, and modifications of cassava starch. Carbohydrate Polymers, 122, 456-480. https://dx.doi.org/10.1016/j.carbpol.2014.10.063

Zylema, B. J., Grider, J. A., Gordon, J., \& Davis, E. A. (1985). Model wheat starch systems heated by microwave irradiation and conduction with equalized heating times. Cereal Chemistry, 62, 447-453. 